\title{
Association between lung function, thoracoabdominal mobility and posture in cystic fibrosis: pilot study
}

\author{
Associação entre função pulmonar, mobilidade toracoabdominal \\ e postura na fibrose cística: estudo piloto
}

\section{Asociación entre función pulmonar, movilidad toracoabdominal $y$ postura en la fibrosis quística: estudio piloto}

\author{
Francisca Pereira Pinto $\mathbb{C}^{[a]}$, Gustavo Vieira Paterlini de Souza $\mathbb{\mathbb { D }}^{[\mathrm{a}, \mathrm{b}]}$, Karine Jacon Sarro $\mathbb{[}$ [c], \\ Cintia Carvalho Bragança Garcia ${ }^{[d]}$, Flávia Marini Paro $[[a] *$
}

[a] Universidade Federal do Espírito Santo (Ufes), Vitória, ES, Brazil

[b] Faculdade Estácio de Sá de Vitória (Fesv), Vitória, ES, Brazil

[c] Universidade Estadual de Campinas (Unicamp), Campinas, SP, Brazil

[d] Hospital Infantil Nossa Senhora da Glória, Vitória, ES, Brazil

\begin{abstract}
Introduction: Deterioration of lung function is the main cause of mortality in cystic fibrosis (CF), so it is essential to study different related factors. Objective: To assess the association of pulmonary function with thoracoabdominal mobility and postural alignment in individuals with CF. Method: A cross-sectional study was performed in individuals with CF (8-17 years). Pulmonary function was assessed by spirometry. Thoracoabdominal mobility and postural alignment were evaluated by photogrammetry using the Postural Assessment Software (PAS/Sapo). Pearson correlation coefficient analysis was performed, and $p<0.05$ was considered significant. Results: The following spirometric variables showed a decrease compared to predicted values: $\mathrm{FEV}_{1}, \mathrm{FEV}_{1} / \mathrm{FVC}$, $\mathrm{PEF}$ and $\mathrm{FEF}_{25-75 \% \text {. }}$ Postural assessment showed alterations in head horizontal alignment (HHA; $2.71 \pm 2.23^{\circ}$ ), acromion horizontal alignment (AHA; $1.33 \pm 1.35^{\circ}$ ), anterior superior iliac spine
\end{abstract}

* FPP: BS, e-mail: pereira.francisca@gmail.com GVPS: BS, e-mail: paterlini.fisio@gmail.com KJS: PhD, e-mail: ksarro@gmail.com CCBG: BS, e-mail: cintiabraganca@yahoo.com.br FMP: PhD, e-mail: flamarp@yahoo.com 
(ASIS) horizontal alignment (ASISHA; $1.11 \pm 0.89^{\circ}$ ), angle between acromia and ASIS (AAASIS; $0.89 \pm 0.39^{\circ}$ ), scapula horizontal asymmetry - T3 (SHAT3; $16.95 \pm 12.03 \%$ ), and asymmetry of the projection of the center of gravity within the base of support in the frontal $(11.45 \pm 8.10 \%)$ and sagittal $(48.98 \pm 18.55 \%)$ planes. A strong positive correlation was found between pulmonary function and thoracoabdominal mobility in the variables anteroposterior mobility of the upper chest (APMUC) and FVC $(r=0.818, p=0.024)$, APMUC and $\mathrm{FEV}_{1}(\mathrm{r}=0.874, \mathrm{p}=0.010)$, and APMUC and $\mathrm{FEF}_{25-75 \%}(\mathrm{r}=0.797, \mathrm{p}=0.032)$. A strong negative correlation was detected between $\mathrm{FEV}_{1} / \mathrm{FVC}$ and AHA $(\mathrm{r}=-0.761, \mathrm{p}=0.047)$. Conclusion: Our study showed in $\mathrm{CF}$ a reduction in pulmonary function, strong positive correlation between APMUC and pulmonary function, high prevalence of kyphoscoliosis and strong negative correlation between AHA and pulmonary function.

Keywords: Cystic Fibrosis. Photogrammetry. Respiratory Mechanics. Posture. Evidence-Based Practice.

\section{Resumo}

Introdução: A deterioração da função pulmonar é a principal causa de mortalidade na fibrose cística (FC), portanto é fundamental estudar diferentes fatores que se relacionam com esta variável. Objetivo: Verificar em indivíduos FC, a associação da função pulmonar com a mobilidade toracoabdominal e a postura. Método: Estudo piloto transversal realizado em indivíduos com FC (08-17 anos). A função pulmonar foi avaliada pela espirometria. A mobilidade toracoabdominal e a postura foram avaliadas por fotogrametria, usando o Software de Avaliação Postural (Sapo). Foi utilizado o Coeficiente de Correlação de Pearson, considerando-se significante $p<0,05$. Resultados: As seguintes variáveis espirométricas apresentaram-se reduzidas em relação ao previsto: $V E F_{1}, V E F_{1} /$ FVC, PFE e FEF ${ }_{25-75 \%}$. Na avaliação postural, foram observadas alterações no alinhamento horizontal da cabeça (AHC, 2,71 $\pm 2,23$ ); alinhamento horizontal acrômios (AHA, 1,33 $\pm 1,35)$; alinhamento horizontal espinhas ilíacas ântero-superiores (AHEIAS, 1,11 $\pm 0,89$ ); ângulo entre dois acrômios e duas espinhas ilíacas ântero-superiores

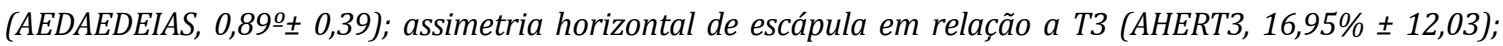
assimetria da projeção do centro de gravidade na base de sustentação no plano frontal $(11,45 \pm 8,10 \%)$ e sagital $(48,98 \pm 18,55 \%)$. Foi encontrada correlação positiva forte entre função pulmonar e mobilidade toracoabdominal nas variáveis: distâncias anteroposterior do tórax superior (DAPTS) e FVC ( $r=0,818 ; p=0,024) ;$ DAPTS e VEF $(r=0,874 ; p=0,010) ; D A P T S$ e $F E F_{25-75 \%}(r=0,797 ; p=0,032)$. Na correlação entre função pulmonar e postura houve correlação negativa forte entre VEF 1 /FVC e AHC ( $r=-0,761 ; p=0.047)$. Conclusão: $O$ estudo mostrou forte correlação positiva entre expansibilidade anteroposterior do tórax superior e função pulmonar, alta prevalência de cifoescoliose e forte correlação negativa entre AHC e função pulmonar.

Palavras-chave: Fibrose Cística. Fotogrametria. Mecânica Respiratória. Postura. Prática Baseada em Evidências.

\section{Resumen}

Introducción: El deterioro de la función pulmonar es la principal causa de mortalidad en la fibrosis quística (FQ) y es fundamental estudiar diferentes factores relacionados con esta variable. Objetivo: Verificar en individuos con FQ la asociación entre la función pulmonar, la movilidad toracoabdominal y la postura. Método: Estudio piloto transversal realizado en individuos con $F Q$ (08-17 años). La función pulmonar fue evaluada por la espirometría. La movilidad toracoabdominal y la postura fueron evaluadas por fotogrametría, usando el Software de Evaluación Postural (Sapo). Se utilizó el Coeficiente de Correlación de Pearson, considerándose significante $p<0,05$. Resultados: En la espirometría se encontraban menores que los valores previstos: $V E F_{1}, V E F_{1} / C V F, P F E$

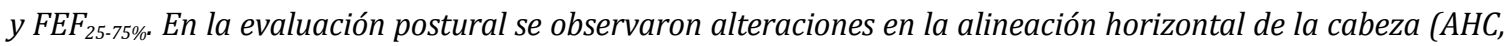
2,71 \pm 2 23); alineación horizontal de los acromios (AHA, 1,33뽀 1,35); alineación horizontal espinas ilíacas

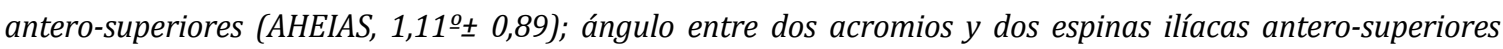
(AEDAEDEIAS, 0,89 \pm 0,39); asimetría horizontal de escápula con respecto a la T3 (AHERT3, 16,95\% $\pm 12,03$ ); asimetría de la proyección del centro de gravedad en la base de sustentación en el plano frontal $(11,45 \pm 8,10 \%)$ y sagital $(48,98 \pm 18,55 \%)$. Se encontró una correlación positiva fuerte entre la función pulmonar y la movilidad 
toracoabdominal en las variables: distancia anteroposterior del tórax superior (DAPTS) y CVF ( $r=0,818$; $p=0,024) ; D_{\text {DPTS y VEF }}(r=0,874 ; p=0,010) ; D_{\text {DAPS y }} \mathrm{FEF}_{25-75 \%}(r=0,797 ; p=0,032) ; y$ en la correlación entre la función pulmonar y la postura hubo una correlación negativa fuerte entre VEF $F_{1} / C V F$ y AHC $(r=-0,761$; $p=0,047)$. Conclusión: El estudio mostró una fuerte correlación positiva entre la expansibilidad anteroposterior del tórax superior y la función pulmonar, alta prevalencia de cifoescoliosis y fuerte correlación negativa entre AHC y la función pulmonar.

Palabras clave: Fibrosis Quística. Fotogrametría. Mecánica Respiratoria. Postura. Práctica Basada en Evidencias.

\section{Introduction}

Cystic fibrosis (CF) is an autosomal recessive genetic disease that has a high mortality rate[1] and a major impact on quality of life starting in childhood [2-3]. The genetic mutations in CF compromise ion transport across epithelial cell membranes, which causes dysfunction of the exocrine glands and consequent dehydration of secretions and obstructions. This leads to multisystemic effects, involving mainly the digestive system, with consequent nutritional deficits, and the respiratory system, whose compromise is the main cause of morbidity and mortality in this disease [1].

Studies conducted after 2000 show a trend towards a slower decline in pulmonary function in CF during childhood compared with earlier studies [4]. In addition, the survival of individuals with $\mathrm{CF}$ has increased due to several factors including: better knowledge of the pathophysiology, early diagnosis, new drug development, treatment in specialized centers and follow-up by an interdisciplinary team [1], considered essential according to national [5] and international [6-7] guidelines, and the recommendation for respiratory physiotherapy at diagnosis and for life [5-7].

Despite these advances, due to the progressive deterioration of the lung parenchyma in $\mathrm{CF}$, most deaths still occur from respiratory failure, which can be triggered or aggravated by respiratory pump failure, which includes the respiratory muscles, rib cage and neuromuscular components, and studies on each of these aspects are important. [8].

In addition to impaired pulmonary function, children with CF have been shown to have reduced peak cough flow (PCF) values [9], high prevalence of musculoskeletal diseases [10] and postural changes [10-11], which have been related to the severity of pulmonary involvement [11], but there are still controversies on the subject [12], which deserves to be better studied.

The use of photogrammetry for postural evaluation is already well established in scientific research and clinical practice [13-16]. In recent years, this resource has also been used for rib cage evaluation [17-18] and increasingly for the assessment of thoracoabdominal mobility in children [19], newborns [20] and adults [21], in populations ranging from athletes [21] to individuals with respiratory diseases [22-23]. However, there has been no other study using this technique to assess thoracoabdominal mobility in children with CF. As it is a reliable, inexpensive, riskfree and easy-to-apply method [24], it is important its use to be incorporated into clinical practice for the longitudinal assessment and follow-up of these patients with regard to postural changes and chest expansion, just as annual spirometry is recommended for monitoring pulmonary function, according to the guidelines.

This study aimed to determine in individuals with CF, the association of pulmonary function with thoracoabdominal mobility and posture, evaluated with photogrammetry.

\section{Methods}

This was a cross-sectional pilot study with a convenience sample, conducted with patients diagnosed with CF, registered at Nossa Senhora da Glória Children's Hospital (HINSG), which is the state pediatric referral center for the treatment of CF in the state of Espírito Santo, Brazil. The research was conducted after the project was approved by the Research Ethics Committee (CEP) of the Federal University of Espírito Santo (Ufes; CAAE 23346413.0.0000.5060; Process No. 494.043), and all procedures were performed in accordance with Resolution 466/12 of the National 
Health Council, which deals with the ethical aspects of research involving humans.

Inclusion criteria were patients diagnosed with CF registered and treated at HINSG, aged 8 to 17 years, who agreed to participate after all explanations and clarification of doubts about the research and signed the informed consent form and whose guardians also agreed and signed the consent form, according to the rules of Resolution $466 / 12$ for conducting research with individuals under 18 years. According to the exclusion criteria, patients were excluded for the following reasons: neuropathies, autism, associated diseases that compromised the comprehension or execution of the evaluation, exacerbation of the pulmonary condition, postoperative recovery period and non-attendance on the evaluation days.

\section{Assessment of pulmonary function by spirometry}

Spirometry was performed at the HINSG CF Service, where these patients are periodically undergoing this examination to monitor disease progression (EasyOne ${ }^{\mathrm{TM}}$, Spirometer DIAGNOSTIC EU 2.24 (c) ndd 2000-2011, Model 2001, Software Version 02.24.00.00). We evaluated: forced vital capacity (FVC), forced expiratory volume in one second $\left(\mathrm{FEV}_{1}\right), \mathrm{FEV}_{1} / \mathrm{FVC}$, Peak expiratory flow (PEF); forced expiratory flow between $25 \%$ and $75 \%$ forced vital capacity $\left(\mathrm{FEF}_{25-75 \%}\right)$. Calibration and spirometric evaluation followed the guidelines of the Brazilian Society of Pulmonology and Physiology [25] and the examination was performed by the HINSG physiotherapist responsible for the periodic spirometry of these patients.

\section{Postural assessment by photogrammetry}

Evaluations using photogrammetry were performed at the Movement and Respiration Biomechanics Laboratory (Bimor), located at the Physical Education and Sports Center of Ufes.

For postural evaluation, the subjects had to wear bathing suits, and 20 markers with analgesic double-sided tape were fixed at the following anatomical points: tragi, acromia, anterior superior iliac spines (Asis), greater femoral trochanter, knee joint line, lateral malleolus, point between the head of the 1st and 2nd metatarsal, inferior angle of the scapulae, posterior superior iliac spines (PSIS), seventh cervical vertebra (C7), and third thoracic vertebra (T3). A photograph was taken in the anterior frontal, right sagittal and posterior frontal planes using a digital camera (GE, A1250, 12.1mpx) while subjects remained in the most natural way possible, with their arms slightly abducted in the frontal plane photograph and slightly flexed in the sagittal plane.

The photographs were analyzed using the Postural Assessment Software (Sapo) [13]. The photos were calibrated from the position of two markers fixed on a plumb line, positioned next to the subject. The two-dimensional coordinates of the markers were obtained and from them, the following variables were calculated: head horizontal alignment (angle between the tragi and the horizontal), acromion horizontal alignment (angle between the acromia and the horizontal), Asis horizontal alignment (angle between the two Asis and the horizontal), angle between the two acromia and the two iliac spines, horizontal asymmetry of the scapula relative to T3, vertical head alignment (angle between the acromion and tragus with the vertical), vertical body alignment (angle between acromion and lateral and vertical malleolus), pelvis horizontal alignment (angle between the Asis, the PSIS and the horizontal) and projection of the center of gravity in the frontal and sagittal planes.

Evaluation of thoracoabdominal mobility by photogrammetry

For the analysis of thoracoabdominal mobility by photogrammetry [24], 12 markers were fixed over specific points of the naked chest and abdomen to demarcate the anterior, posterior and lateral regions of the chest and abdomen. Due to anatomical, structural and functional differences, the thoracoabdominal wall was divided into upper chest, lower chest and abdomen. To calculate upper thoracic mobility, the coordinates of 4 markers positioned on the chest on the fifth rib line were used. To calculate lower thoracic mobility, the coordinates of 4 markers positioned on the chest on the line of the xiphoid process were used. To calculate abdominal mobility, the coordinates of 4 markers positioned on the abdomen on the umbilical scar line were used.

The subjects remained standing with their hands resting on their ears, positioned next to a plumb line with 2 markers of known position, 
and were photographed by 2 cameras (GE, A1250, $12.1 \mathrm{mpx}$ ) simultaneously, one in the frontal plane and one in the sagittal plane. Two moments were photographed: the first with the subject at maximum inspiration, and the second at maximum expiration. The images were loaded in the Sapo, where they were calibrated from the plumb line markers, and the linear distances between the markers were computed, representing the transverse and anteroposterior diameters of the upper chest, lower chest and abdomen. Thoracoabdominal mobility was characterized by the difference between the calculated maximum inspiratory distance and the calculated maximum expiratory distance.

\section{Statistical analysis}

Statistical analysis was performed using the Statistical Package for Social Sciences software (IBM SPSS Statistics 22, IBM, Armonk, NY, USA). In the descriptive analyses, categorical variables were presented in their absolute and relative frequencies and numerical variables as mean \pm standard deviation (SD). Data were considered parametric if the ShapiroWilk test showed normality, and Pearson correlation coefficient ( $\mathrm{r}$ ) was used to determine correlations. Correlation strength was assessed by the correlation coefficient value $(\mathrm{r})$ according to the following criteria: $0<\mathrm{r}<0.3=$ weak correlation; $0.3 \leq \mathrm{r}<0.6$, = moderate correlation; $0.6 \leq r<0.9=$ strong correlation; $0.9 \leq \mathrm{r}<1$ = very strong correlation [26]. $\mathrm{p}<0.05$ was considered significant.

\section{Results}

Initially, 42 individuals diagnosed with $\mathrm{CF}$, in the study age group and cared for at HINSG, were initially selected, of whom the following were excluded for the noted reasons: two had autism; three did not attend the evaluations on the scheduled days; 26 did not agree to participate because they lived in other municipalities; and 3 did not agree to participate for other reasons. Finally, eight individuals with $\mathrm{CF}$, aged between 8 and 17 years (mean $12.13 \pm 3.09$ years), equally distributed between genders were evaluated. Regarding thorax morphology, six individuals had kyphoscoliosis (75\%) and two had normal morphology (25\%).

$\mathrm{FEV}_{1}$ and $\mathrm{FEV}_{1} / \mathrm{FVC}$ means were below $80 \%$ predicted and $\mathrm{PEF}$ and $\mathrm{FEF}_{25-75 \%}$ means were below
$70 \%$ predicted, considering Polgar \& Promadhat normality reference values, as recommended by the Brazilian Society of Pulmonology and Tisiology for children and adolescents [25]. Details on pulmonary function are presented in Table 1.

Table 1 - Clinical and demographic characteristics of the sample

\begin{tabular}{|c|c|}
\hline & Mean \pm SD \\
\hline Age (years) & $12.13 \pm 3.09$ \\
\hline Height (m) & $1.55 \pm 0.20$ \\
\hline Weight (kg) & $46.85 \pm 20.62$ \\
\hline BMI $\left(\mathrm{kg} / \mathrm{m}^{2}\right)$ & $18.22 \pm 4.01$ \\
\hline $\mathrm{FEV}_{1}(\mathrm{~L})$ & $2.42 \pm 1.30$ \\
\hline $\mathrm{FEV}_{1}(\%$ pred) & $76.29 \pm 28.06$ \\
\hline FVC (L) & $3.19 \pm 1.41$ \\
\hline FVC (\% pred) & $95.00 \pm 27.63$ \\
\hline $\mathrm{FEV}_{1} / \mathrm{FVC}(\%)$ & $73.16 \pm 13.04$ \\
\hline $\mathrm{FEV}_{1} / \mathrm{FVC}(\%$ pred) & $78.14 \pm 13.58$ \\
\hline PEF (L/s) & $5.06 \pm 2.69$ \\
\hline PEF (\% pred) & $68.17 \pm 29.05$ \\
\hline $\mathrm{FEF}_{25-75}(\mathrm{~L} / \mathrm{s})$ & $2.14 \pm 1.53$ \\
\hline $\mathrm{FEF}_{25-75}$ (\% pred) & $66.29 \pm 50.83$ \\
\hline
\end{tabular}

Note: IMC = body mass index; $\mathrm{FEV}_{1}=$ forced expiratory volume in one second; \% pred, percent predicted; FVC = forced vital capacity; $\mathrm{PEF}=$ peak expiratory flow; $\mathrm{FEF}_{25-75}=$ forced expiratory flow between 25 and $75 \%$ FVC.

Regarding the postural variables evaluated by Sapo, considering that a positive or negative sign represented the direction of rotation of the variable, the data presented as mean and SD were considered as absolute values. The reference value given by the Sapo program is 0 degrees.

According to the reference values, changes were observed in the following variables: HHA, with a mean of $2.71 \pm 2.23^{\circ}$; AHA, with mean of $1.33 \pm 1.35^{\circ}$; ASISHA, with a mean of $1.11 \pm 0.89^{\circ}$; AAASIS, with a mean of $0.89 \pm 0.39^{\circ}$; and SHAT3, with a mean of $16.95 \pm 12.03^{\circ}$ (Table 2).

Changes in the balance of these patients were also observed, as there was asymmetry of the projection of the center of gravity within the base of support in the frontal plane, with a mean of $11.45 \pm 8.10 \%$, a result showing alteration in the lateral displacement and asymmetry of the projection of the center of gravity within the base of support in the sagittal plane, with a mean of $48.98 \pm 18.55 \%$, demonstrating an anteroposterior displacement (Table 2). 
Table 2 - Postural evaluation by photogrammetry

\begin{tabular}{lr}
\hline Variable & Mean \pm SD \\
\hline HHA $\left(^{\circ}\right)$ & $2.71 \pm 2.23$ \\
AHA $\left(^{\circ}\right)$ & $1.33 \pm 1.35$ \\
ASISHA $\left(^{\circ}\right)$ & $1.11 \pm 0.89$ \\
AAASIS $\left(^{\circ}\right)$ & $0.89 \pm 0.39$ \\
HHAC7 $\left(^{\circ}\right)$ & $44.84 \pm 6.14$ \\
HVAA $\left(^{\circ}\right)$ & $15.50 \pm 4.85$ \\
TVA $\left(^{\circ}\right)$ & $4.10 \pm 3.14$ \\
PHA $\left({ }^{\circ}\right)$ & $13.23 \pm 5.20$ \\
SHAT3 (cm) & $16.95 \pm 12.03$ \\
Dislocation of projection of center of gravity: & \\
FPA (\%) & $11.45 \pm 8.10$ \\
SPA (\%) & $48.98 \pm 18.55$ \\
\hline
\end{tabular}

Note: $H H A=$ head horizontal alignment; $A H A=$ acromion horizontal alignment; ASISHA = anterior superior iliac spine horizontal alignment; AAASIS $=$ angle between acomia and anterior superior iliac spines; $\mathrm{HHAC7}=$ head horizontal alignment $\mathrm{C} 7$; HVAA = head vertical alignment acromia; TVA = trunk vertical alignment; PHA = pelvis horizontal aligment; SHAT3 = scapula horizontal assymetry relative to T3; FPA = frontal plane asymmetry; $\mathrm{SPA}=$ sagittal plane asymmetry.

Mobility in transverse abdominal distance (TAD) was negative, with a mean of $-1.09 \pm 0.81 \mathrm{~cm}$. Importantly, the negative TAD value does not mean that the mobility was negative, but rather that the distance was greater at expiration than at inspiration, indicating a paradoxical breathing pattern in this measure (Table 3).
Table 3 - Thoracoabdominal mobility evaluated by photogrammetry (cm)

\begin{tabular}{clc}
\hline & \multicolumn{1}{c}{ Sex } & Mean \pm SD \\
\hline \multirow{4}{*}{ TMUC } & General & $1.40 \pm 0.62$ \\
& Male & $1.53 \pm 0.57$ \\
& Female & $1.28 \pm 0.74$ \\
& General & $1.33 \pm 0.59$ \\
TMLC & Male & $1.30 \pm 0.42$ \\
& Female & $1.35 \pm 0.80$ \\
& General & $-1.09 \pm 0.81$ \\
TMA & Male & $-1.05 \pm 1.06$ \\
& Female & $-1.13 \pm 0.63$ \\
& General & $1.88 \pm 0.80$ \\
APMUC & Male & $2.03 \pm 1.16$ \\
& Female & $1.73 \pm 0.31$ \\
& General & $1.95 \pm 0.96$ \\
APMLC & Male & $1.68 \pm 1.35$ \\
& Female & $2.23 \pm 0.35$ \\
& General & $1.14 \pm 0.98$ \\
APMA & Male & $1.30 \pm 0.45$ \\
& Female & $0.98 \pm 1.40$ \\
\hline
\end{tabular}

Note: TMUC $=$ transverse mobility of upper chest; TMLC = transverse mobility of lower chest; TMA = transverse mobility of abdomen; APMUC $=$ anteroposterior mobility of upper chest; APMLC $=$ anteroposterior mobility of lower chest; APMA $=$ anteroposterior mobility do abdomen.

Table 4 shows the correlation between thoracoabdominal mobility and pulmonary function. Astrong positive correlation was found between the following variables: APMUC and FVC $(\mathrm{r}=0.818$; $\mathrm{p}=0.024)$; APMUC and FEV $_{1}(\mathrm{r}=0.874 ; \mathrm{p}=0.010)$; and APMUC and $\mathrm{FEF}_{25-75 \%}(\mathrm{r}=0,797 ; \mathrm{p}=0,032)$.

In the correlation between the postural variables and pulmonary function, a strong negative correlation was observed between the following variables. $\mathrm{FEV}_{1}$ / FVC and HHA (Table 5).

Table 4 - Correlation between thoracoabdominal mobility and pulmonary function (\% pred)

\begin{tabular}{|c|c|c|c|c|c|c|c|c|c|c|c|c|}
\hline \multirow{2}{*}{$\begin{array}{l}\text { Pulmonary } \\
\text { function }\end{array}$} & \multicolumn{2}{|l|}{ TMUC } & \multicolumn{2}{|l|}{ TMLC } & \multicolumn{2}{|l|}{ TMA } & \multicolumn{2}{|l|}{ APMUC } & \multicolumn{2}{|l|}{ APMLC } & \multicolumn{2}{|l|}{ APMA } \\
\hline & $r$ & $\mathrm{p}$-valor & $r$ & $\mathrm{p}$-valor & $r$ & $\mathrm{p}$-valor & $r$ & p-valor & $r$ & p-valor & $r$ & p-valor \\
\hline FVC & 0.646 & 0.117 & -0.081 & 0.863 & -0.243 & 0.599 & 0.778 & $0.039 *$ & 0.401 & 0.373 & 0.577 & 0.175 \\
\hline $\mathrm{FEV}_{1}$ & 0.569 & 0.183 & -0.368 & 0.417 & -0.194 & 0.678 & 0.864 & $0.012^{*}$ & 0.554 & 0.197 & 0.303 & 0.508 \\
\hline $\mathrm{FEV}_{1} / \mathrm{FVC}$ & 0.080 & 0.864 & -0.674 & 0.097 & -0.132 & 0.778 & 0.555 & 0.196 & 0.541 & 0.210 & -0.082 & 0.861 \\
\hline PEF & 0.581 & 0.227 & -0.083 & 0.876 & -0.405 & 0.426 & 0.730 & 0.099 & 0.288 & 0.580 & -0.084 & 0.875 \\
\hline $\mathrm{FEF}_{25-75}$ & 0.314 & 0.493 & -0.653 & 0.112 & -0.081 & 0.862 & 0.785 & $0.036^{*}$ & 0.741 & 0.056 & -0.026 & 0.956 \\
\hline
\end{tabular}

Note: * Statistically significant $(p<0.05) ; r=$ Pearson correlation coefficient $(0<r<0.3=$ weak correlation; $0.3 \leq r<0.6=$ moderate correlation; $0.6 \leq r<0.9=$ strong correlation; $0.9 \leq r<1=$ verty strong correlation); TMUC = transverse mobility of upper chest; TMLC = transverse mobility of lower chest; TMA = transverse mobility of abdomen; APMUC = anteroposterior mobility of upper chest; APMLC = anteroposterior mobility of lower chest; DAPA = anteroposterior mobility of abdomen; $\mathrm{FEV}_{1}=$ forced expiratory volme in one second; \% pred, percentage do predito; FVC = forced vital capacity; PEF = peak expiratory flow; FEF $_{25-75}=$ forced expiratory flow between 25 and $75 \%$ FVC. 
Table 5 - Correlation between postural evaluation and pulmonary function

\begin{tabular}{lcccccccccc}
\hline \multirow{2}{*}{ Postural evaluation } & \multicolumn{3}{c}{ FVC } & \multicolumn{2}{c}{ FEV $_{1}$} & \multicolumn{2}{c}{ FEV $/$ FVC } & \multicolumn{2}{c}{ PEF } & \multicolumn{2}{c}{ FEF $_{25-75 \%}$} \\
\cline { 2 - 11 } & $\mathbf{r}$ & $\mathbf{p}$-value & $\mathbf{r}$ & $\mathbf{p}$-value & $\mathbf{r}$ & $\mathbf{p}$-value & $\mathbf{r}$ & $\mathbf{p}$-value & $\mathbf{r}$ & $\mathbf{p}$-value \\
\hline HHA & -0.360 & 0.428 & -0.635 & 0.126 & $\mathbf{- 0 . 7 6 1}$ & $\mathbf{0 . 0 4 7}$ & -0.610 & 0.198 & -0.636 & 0.125 \\
AHA & 0.363 & 0.424 & -0.008 & 0.987 & -0.433 & 0.332 & -0.277 & 0.595 & -0.341 & 0.455 \\
ASISHA & 0.375 & 0.407 & 0.052 & 0.911 & -0.419 & 0.350 & 0.086 & 0.871 & -0.286 & 0.535 \\
AAASIS & 0.118 & 0.801 & -0.011 & 0.981 & -0.159 & 0.733 & -0.454 & 0.366 & 0.081 & 0.863 \\
HHAC7 & 0.012 & 0.980 & -0.276 & 0.550 & -0.625 & 0.133 & -0.616 & 0.193 & -0.463 & 0.295 \\
HVAA & 0.503 & 0.250 & 0.571 & 0.180 & 0.471 & 0.286 & 0.510 & 0.301 & 0.508 & 0.245 \\
TVA & 0.058 & 0.901 & -0.185 & 0.692 & -0.323 & 0.480 & -0.259 & 0.620 & -0.396 & 0.380 \\
PHA & 0.005 & 0.991 & -0.326 & 0.475 & -0.555 & 0.196 & -0.309 & 0.551 & -0.732 & 0.062 \\
SHAT3 & 0.019 & 0.968 & 0.232 & 0.616 & 0.418 & 0.350 & 0.244 & 0.641 & 0.421 & 0.347 \\
FPA (\%) & -0.417 & 0.351 & -0.476 & 0.280 & -0.642 & 0.120 & -0.687 & 0.131 & -0.299 & 0.515 \\
SPA (\%) & -0.535 & 0.215 & -0.298 & 0.517 & 0.122 & 0.794 & 0.215 & 0.682 & -0.048 & 0.918 \\
\hline
\end{tabular}

Note: *Statistically significant $(p<0.05) ; r=$ Pearson correlation coefficient $(0<r<0.3=$ weak correlation; $0.3 \leq r<0.6=$ moderate correlation; $0.6 \leq r<0.9=$ strong correlation; $0.9 \leq r<1=$ very strong correlation); $\mathrm{HHA}=$ head horizontal alignment; $\mathrm{AHA}=$ acromion horizontal alignment; $\mathrm{ASISHA}=$ anterior superior iliac spine horizontal alignment; AAASIS $=$ angle between acromia and anterior superior iliac spines; HHAC7 = head horizontal alignment C7; HVAA = head vertical alignment acromia; TVA = trunk vertical alignment; PHA = pelvis horizontal alignment; SHAT3 = scapula horizontal asymmetry relative to T3; FPA = frontal plane asymmetry (gravity dislocation); SPA = sagittal plane asymmetry (gravity dislocation); $\mathrm{FEV}_{1}=$ forced expiratory volume in one second; \% pred, percent predicted; $\mathrm{FVC}=$ forced vital capacity.

\section{Discussion}

This study aimed to determine if there is an association of pulmonary function with thoracoabdominal mobility and posture in children and adolescents with CF. The main finding was a strong positive correlation between anteroposterior mobility of the upper chest and pulmonary function, more specifically with FVC, $\mathrm{FEV}_{1}$ and $\mathrm{FEF}_{25-75}$, that is, the lower the lung function, the greater the reduction in mobility. Although this relationship has not been previously evaluated in children with CF using photogrammetry, a recent publication showed that in adults with COPD, impairment of lung function was associated with reduced upper chest quadrant mobility assessed by photogrammetry [22]. A systematic review has shown that the progression of pulmonary dysfunction in CF is nonlinear, with high variability in the decline rate throughout life. [4]

The $\mathrm{FEF}_{25-75 \%}$ correlated positively with air trapping in individuals with $\mathrm{CF}$ and mild pulmonary impairment [27]. In the present study, the $\mathrm{FEF}_{25-75 \%}$ showed a greater decrease in relation to the predicted values compared to $\mathrm{FEV}_{1}$ and FVC. This result is consistent with the literature, showing that the decline in $\mathrm{FEF}_{25-75 \%}$ precedes changes in $\mathrm{FEV}_{1}$ and $\mathrm{FVC}$, because it reflects the changes in the peripheral airways, considered the "silent zone" due to its enormous cross-sectional area, where there can be substantial obstruction and deterioration even in the presence of normal $\mathrm{FEV}_{1}$ and FVC [28]. The means observed in the pulmonary function parameters characterize mild obstructive disorder [25] and are similar to the means reported in other studies conducted in individuals with $\mathrm{CF}$ in the same age group [4].

Therefore, the strong positive correlation observed between anteroposterior mobility of the upper chest and pulmonary function suggests that photogrammetry evaluation may be able to detect changes in thoracic mobility in CF children even in the early stages of pulmonary deterioration, contributing to the monitoring and evaluating the optimization of respiratory therapy.

Measurement of thoracoabdominal mobility by photogrammetry is a low-cost, simple imageacquisition method that assesses thoracoabdominal movement two-dimensionally during specific respiratory maneuvers [24]. The trunk is divided into three parts, since each part has the action of a different musculature. In the upper chest region, there is the action of intercostal muscles and cervical accessory muscles mainly. The intercostal muscles and diaphragm act in the lower chest, while the abdomen region has the action of the diaphragm and abdominal muscles [29]. The correlation between 
pulmonary function and upper chest mobility may be related to the deterioration of intercostal and accessory muscle function due to their shortening and/or mechanical disadvantage due to changes in rib cage conformation. This hypothesis is reinforced by the strong negative correlation found in the present study between pulmonary function and HHA, indicating that when pulmonary function worsens, there is greater misalignment of the head. The muscles responsible for head alignment, such as scalene and sternocleidomastoid, also participate in breathing by elevating the upper chest. Constant monitoring of these parameters should be recommended, as with spirometry, since it may contribute to the prevention and early treatment of these changes.

PEF averaged below 70\% predicted, which is considered the lower limit of normality for this variable [25]. Reduction in PEF may indicate that PCF is also reduced, as in obstructive pulmonary diseases such as CF, reduced expiratory flow and increased viscosity of bronchial secretion are probably the leading causes of ineffective cough [30]. In addition, PEF and PCF values were similar in an earlier study in CF patients [31], and PCF reduction has been reported in children and adolescents with CF [9]. This variable deserves attention because it is known that cough is an important physiological mechanism for bronchial hygiene, which is essential for the prevention of recurrent infections and bacterial colonization, which accelerate the decline of pulmonary function in CF $[1,32,33]$, with an impact on quality of life $[2,3]$ and mortality due to the disease [1, 32, 33].

The mean negative OTD $(-1.09 \pm 0.81)$ suggests that the breathing pattern was paradoxical during deep inspiration, which was also observed in a study with asthmatic adolescents [34]. The paradoxical movement between the chest and abdomen may be the result of an incoordination between the intercostal muscles and the diaphragm. Importantly, thoracoabdominal mobility was assessed from maximal inspirations, so unfamiliarity with this type of breathing may have led to this uncoordinated pattern of movement between the chest and abdomen, indicating the need for training in the management of people with CF.

The results showed a high prevalence of thoracic kyphosis, which corroborates other studies with children [12,35] and adolescents with
CF $[12,35,36]$, and may be responsible for the great anteroposterior imbalance evidenced in this study by the great asymmetry of the projection of the center of gravity on the support base in the sagittal plane ( $48.98 \pm 18.55 \%)$, as kyphosis shifts the center of gravity in this direction. However, the postural deviations identified by photogrammetric evaluation, which basically considered the alignment of the head, shoulders and pelvis, can be considered small. Postural changes in individuals with CF have a multifactorial etiology. Problems with bone mineralization are common in $\mathrm{CF}$ and may predispose to increased fractures, vertebral wedging and thoracic kyphosis [10]. It has also been hypothesized that due to increased respiratory work, the anterior trunk muscle chains are more recruited than the posterior chains, with the consequent myofascial shortening of the trunk flexor chains, which predisposes to increased thoracic kyphosis. In addition, constant shortening and contraction of the respiratory accessory muscles (scalene, sternocleidomastoid, pectoral, serratus, and abdominal) may cause axial compression of the anterior faces of the vertebral body and may increase the risk of fractures due to bone demineralization [36].

In adults with $\mathrm{CF}$, deterioration in lung function has been associated with increased dorsal kyphosis $[11,36]$, with changes in vertical alignment of the chest [37] and also with increased prevalence of vertebral fractures [36]. These postural deviations alter the conformation of the rib cage structures, placing the respiratory muscles at a mechanical disadvantage and, therefore, may also contribute for the reduction of thorax mobility. However, in children and adolescents with the disease, this relationship does not seem to be present yet. A study of individuals aged 7 to 19 years showed that, despite the high prevalence of kyphosis, postural changes were unrelated to pulmonary function [12], which was also observed in a recent study of individuals with average age of 14.04 years [36], which supports our results.

The convenience sample and the small number of participants were important limitations of the study. However, it is important to highlight that although the sample was small, the data were collected at a state pediatric referral center for CF treatment, to which all Espírito Santo patients with established CF diagnosis are referred, including babies testing 
positive in neonatal screening for diagnostic confirmation procedures $[38,39]$. Moreover, it is noteworthy that, even with the small number of individuals, the normality test showed that the data were parametric. Another limitation of the study was the fact that photogrammetry does not yet have reference values for thoracoabdominal mobility.

\section{Conclusion}

The study showed a strong positive correlation between anteroposterior upper chest mobility and pulmonary function, which showed mild obstructive involvement. In addition, there was a high prevalence of kyphoscoliosis, and HHA showed a strong negative correlation with pulmonary function, i.e., the worse the pulmonary function, the greater the horizontal misalignment of the head. Photogrammetry proved to be effective in detecting changes in thoracoabdominal mobility in children and adolescents with CF, even in cases of mild obstruction, suggesting that its use may be incorporated as an evaluation and monitoring tool in respiratory functional rehabilitation programs for patients with CF, and it is important to develop further studies and protocols with reference values.

\section{References}

1. Elborn JS. Cystic fibrosis. Lancet. 2016;388:2519-31.

2. Abbott J, Morton AM, Hurley MA, Conway SP. Longitudinal impact of demographic and clinical variables on health-related quality of life in cystic fibrosis. BMJ Open. 2015;5(5):e007418.

3. Silva LA, Lima ACP, Wittmer VL, Liberato FMG, Arpini LSB, Paro FM. Qualidade de vida de crianças e adolescentes com fibrose cística: importância da imagem corporal e impacto do estado nutricional, idade e raça/cor na percepção dos pacientes e responsáveis. Demetra. 2018;13(3):675-93.

4. Harun SN, WainwrightC, Klein K, Hennig S. A systematic review of studies examining the rate of lung function decline in patients with cystic fibrosis. Paediatr Respir Rev. 2016;20:55-66.

5. Athanazio RA, Silva Filho LVRF, Vergara AA, Ribeiro AF, Riedi CA, Procianoy EFA, et al. Diretrizes brasileiras de diagnóstico e tratamento da fibrose cística. J Bras Pneumol. 2017;43(3):219-45.
6. Smyth AR, Bell SC, Bojcin S, Bryon M, Duff A, Flume $P$, et al. European Cystic Fibrosis Society standards of care: best practice guidelines. J Cyst Fibros. 2014;13(Suppl 1):S23-42.

7. Button BM, Wilson C, Dentice R, Cox NS, Middleton A, Tannenbaum E, et al. Physiotherapy for cystic fibrosis in Australia and New Zealand: a clinical practice guideline. Respirol. 2016;21(4):656-67.

8. Dassios T. Determinants of respiratory pump function in patients with cystic fibrosis. Paediatr Respir Rev. 2015;16(1):75-9.

9. Vaz BMB, Falcão JB, Liberato FMG, Arpini LSB, Wittmer VL, Paro FM. Associação entre pico de fluxo da tosse, colonização bacteriana e estado nutricional em crianças e adolescentes com fibrose cística. Fisioter Bras. 2018;19(5):631-40.

10. Tattersall R, Walshaw MJ. Posture and cystic fibrosis. J R Soc Med. 2003;96(Suppl 43):18-22.

11. Cherobin IA, Dalcin PDTR, Ziegler B. Association between lung function, physical activity level and postural evaluation variables in adult patients with cystic fibrosis. Clin Resp J. 2018;12(4):1510-7.

12. Okuro R, Correa EP, Conti P, Ribeiro J, Ribeiro M, Schivinski C. Influence of thoracic spine postural disorders on cardiorespiratory parameters in children and adolescents with cystic fibrosis. J Pediatr. 2012;88(4):310-6.

13. Ferreira EAG, Duarte M, Maldonado EP, Burke TN, Marques AP. Postural assessment software (PAS/SAPO): validation and reliabiliy. Clinics. 2010;65(7):675-81.

14. Santos LDM, Souza TP, Crescentini MCV, Poletto PR, Gotfryd AO, Yi LC. Avaliação postural por fotogrametria em pacientes com escoliose idiopática submetidos à artrodese: estudo piloto. Fisioter Mov. 2017;25(1):165-73.

15. Aroeira RMC, Furlan RMMM, Pertence AEM, Las Casas EB, Greco M. Relationship between head posture and lumbar curve in a sitting position: a biomechanical study. Fisioter Mov. 2017;30(3):453-61. 
16. Brito APNP, Franco-Salerno GR, Prado-Rico JM, Souza Fernandes SM. Métodos qualitativos e quantitativos de avaliação do alinhamento postural. Fisioter Bras. 2016;17(3):275-84.

17. Rebouças FP, Sperandio EF, Alexandre AS, Yi LC, Gotfryd AO, Vidotto MC. The use of photogrammetry to evaluate chest wall after arthrodesis in patients with Adolescent Idiopathic Scoliosis. Fisioter Mov. 2017;30(Suppl 1):S307-16.

18. Saraiva BMA, Stella TC, Araujo GS, Sperandio EF, Dourado VZ, Vidotto MC. Thoracic changes and exercise capacity in patients with adolescent idiopathic scoliosis. Fisioter Mov. 2017;30( Suppl 1):S209-17.

19. Ricieri DDV, Rosário Filho NA. Efetividade de um modelo fotogramétrico para a análise da mecânica respiratória toracoabdominal na avaliação de manobras de isovolume em crianças. J Bras Pneumol. 2009;35(2);144-50.

20. Guerra JIA, Nagem DAP, Moran CA, Gomes VLS, Carvalho JMCD, Pereira SA. Thoracoabdominal mobility evaluation by photogrammetry in newborns after expiratory flow increase technique. Fisioter Mov. 2017;30(4):789-95.

21. 21. Sarro KJ, Silvatti AP, Barros RM. Coordination between ribs motion and thoracoabdominal volumes in swimmers during respiratory maneuvers. J Sports Sci Med. 2008;7(2):195-200.

22. Morais N, Cruz J, Marques A. Posture and mobility of the upper body quadrant and pulmonary function in COPD: an exploratory study. Braz J Phys Ther. 2016;20(4):345-54.

23. Gonçalves MA, Francisco DDS, Medeiros CSD, Brüggemann AKV, Mazo GZ, Paulin E. Postural alignment of patients with Chronic Obstructive Pulmonary Disease. Fisioter Mov. 2017;30(3):549-58.

24. Sarro KJ, Mombrini CL, Tonole TB. Reliability and minimal detectable change of thoracoabdominal mobility measurements using photogrammetry. Physiother Theory Pract. 2018;34(9):730-9.
25. Rodrigues JC, Cardieri JMA, Bussamra MHCF, Nakaie CMA, Almeida MB, Silva Filho LVF, et al. Provas de função pulmonar em crianças e adolescentes. J Pneumol. 2002;28(Supl 3):S207-21.

26. Callegari J, Sidia M. Bioestatística: princípios e aplicações. Porto Alegre: Artmed; 2003. p. 90.

27. Bonnel AS, Song SMH, Kesavarju K, Newaskar M, Paxton CJ, Bloch DA, et al. Quantitative air-trapping analysis in children with mild cystic fibrosis lung disease. Pediatr Pulmonol. 2004;38(5):396-405.

28. Tiddens HA. Detecting early structural lung damage in cystic fibrosis. Pediatr Pulmonol. 2002;34(3):228-31.

29. Ward ME, Ward JW, Macklem PT. Analysis of human chest wall motion using a two-compartment rib cage model. J Appl Physiol. 1985;72(4):1338-47.

30. 30. Freitas FS, Parreira VF, Ibiapina CC. Aplicação clínica do pico de fluxo da tosse: uma revisão de literatura. Fisioter Mov. 2010;23(3):495-502.

31. Vilozni D, Lavi M, Ofek M, Sarouk I, Efrati O. Cough characteristics and FVC maneuver in cystic fibrosis. Respir Care. 2014;59(12):1912-7.

32. Moore JE, Mastoridis P. Clinical implications of Pseudomonas aeruginosa location in the lungs of patients with cystic fibrosis. J Clin Pharm Ther. 2017;42(3):259-67.

33. Adler FR, Liou TG. The dynamics of disease progression in cystic fibrosis. PLos ONE. 2016;11(6):e0156752.

34. Basso RP, Regueiro EMG, Jamami M, Di Lorenzo VAP, Costa D. Relação da medida da amplitude tóraco-abdominal de adolescents asmáticos e saudáveis com seu desempenho físico. Fisioter Mov. 2011;24(1):107-14.

35. Kenis-Coskun O, Karadag-Saygi E, Bahar-Ozdemir Y, Gokdemir Y, Karadag B, Kayhan 0. The involvement of musculoskeletal system and its influence on postural stability in children and young adults with cystic fibrosis. Ital J Pediatr. 2017;43(1):106. 
36. Tejero García S, Giráldez Sánchez M, Cejudo P, Quintana Gallego E, Dapena J, García Jiménez R, et al. Bone health, daily physical activity, and exercise tolerance in patients with cystic fibrosis. Chest. 2011;140(2):475-81.

37. Penafortes JTS, Guimarães FS, Moço VJR, Almeida VP, Dias RF, Lopes AJ. Associação entre postura, função pulmonar e capacidade funcional na fibrose quística. Rev Port Pneumol. 2013;19(1):1-6.

38. Bonfim IM, Córdova ELM, Garcia CCB, Paro FM. Perfil dos pacientes com fibrose cística atendidos no centro de referência pediátrico do Espírito Santo. Rev Bras Pesqui Saude. 2019;21(1):80-5.
39. Grupo Brasileiro de Estudos de Fibrose Cística. Registro Brasileiro de Fibrose Cística (REBRAFC). 2014 [cited 2019 Feb 6]. Available from: https://bit.ly/2k24WIS
Received in $02 / 15 / 2019$

Recebido em 15/02/2019

Recibido en 15/02/2019

Approved in 07/01/2020

Aprovado em 07/01/2020

Aprobado en 07/01/2020 